\title{
Evaluation of the carrying capacity of the building structures in the industrial heritage for its adaptation
}

\author{
Sergej Kudrjavtsev ${ }^{1, *}$ \\ ${ }^{1}$ Ural Federal University, Department of civil and industrial engineering, 620002 Yekaterinburg, \\ Russian Federation
}

\begin{abstract}
The article presents the results of verification calculations of carrying capacity of building structures of "White Tower". This former water tower is a constructivist monument of state-wide significance and one of the oldest reinforced concrete structures in Yekaterinburg. Currently the design of adaptation of the object as a museum or an exhibition hall is being developed. The purpose of the study is to answer the question: Will the structures of the 1930 s withstand the loads regulated by modern building codes? The results of carried out field inspections and a finiteelement model of the LIRA-SAPR software are also described. The data of the weakest sections and elements of the structure are presented. The result of the work will allow carrying out a complex of efforts for the restoration of building structures of the object and will help in deciding whether to develop one or another alternative for its adaptation.
\end{abstract}

\section{Introduction - Brief history of the construction}

There are more than 15 thousand monuments of federal significance in Russian Federation. One of these is the former water tower, better known as the "White Tower" in Yekaterinburg [1]. This facility is a remarkable example of the industrial architecture of the Soviet avant-garde and one of the first reinforced concrete structures in Sverdlovsk (the former name of Yekaterinburg).

The initial outline design of the tower was developed by the architect M.V. Reisher in 1929 [2]. The draft project provided for installation of a reinforced concrete water tank with a volume of $540 \mathrm{~m}^{3}$, an observation deck on the roof of the structure and a bus stop pavilion at the base of the tower. The support of the water tank was provided on two reinforced concrete columns and on the internal stairwell structure. For technological reasons a steel tank was provided instead of a reinforced concrete water tank, with its volume increased to $700 \mathrm{~m}^{3}$. In addition, two extra external columns were added in order to support the structure of the tank. Constructive drawings of the tower were developed by the design office "Techbeton", Moscow [3]. The design drawings for water tank of Otto Intze system were carried out by the design department of "Uralmash" factory. It was the first construction of this sort made by welding and without rivets in USSR. The construction of tower was

\footnotetext{
*Corresponding author: s.v.kudryavtsev@urfu.ru
} 
carried out in 1930-1931. During hydraulic tests taken on June 5, 1931, the bottom of the tank collapsed. After that it was decided to make a new tank bottom from reinforced concrete, retaining the steel walls of the tank. The tower was commissioned in 1931. In the 1960 s the tower ceased to perform its basic functions in water supply of residential houses and the question arose of its further conversion to other needs. In 1971 an architect M.V. Reisher developed a project to house cafe in the tower, but it was never implemented, thus since the 1970 s the tower is not functioning as a water tower.
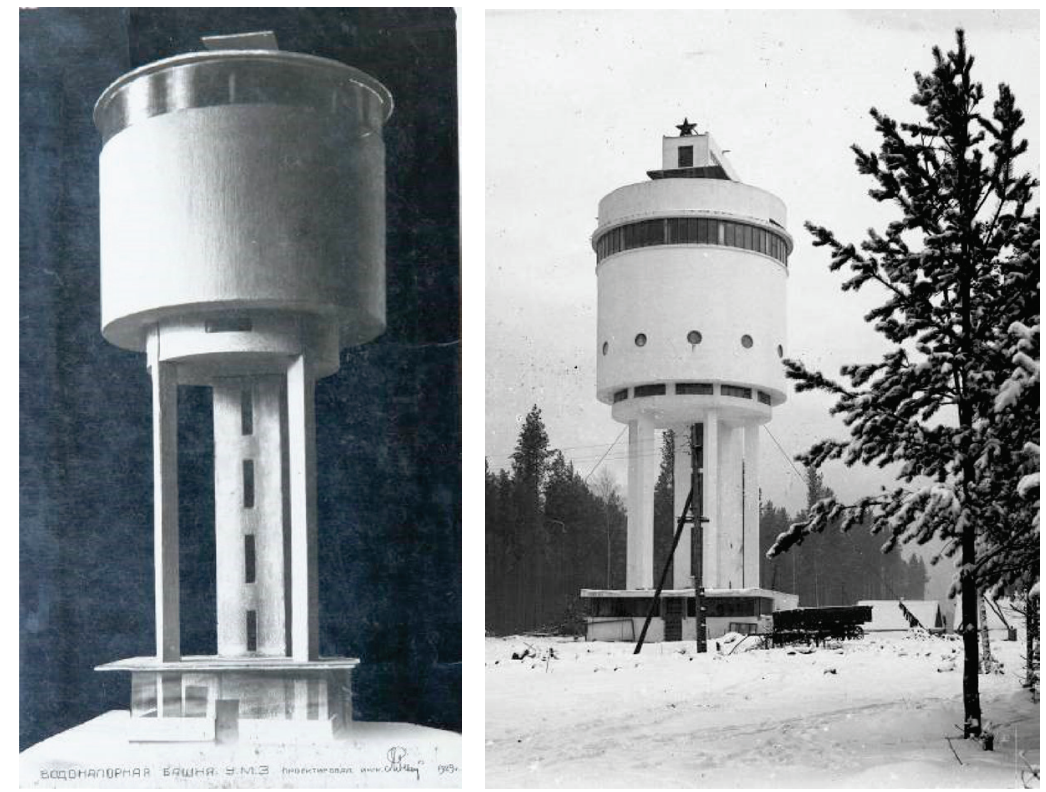

Fig. 1. Sketch of the water tower, designed by the architect M.V. Reisher in 1929 and structure completed by construction in 1931. [2]

\section{Characteristics of building structures}

Nowadays the structure represents two interrelated spatial volumes: a cylindrical part with a diameter of $13.5 \mathrm{~m}$, supported by four reinforced concrete external columns and a prismatic part of a width of $3.2 \mathrm{~m}$ and a length of $5.75 \mathrm{~m}$.

In the cylindrical volume of the structure there was a water tank which is partially dismantled nowadays and only the reinforced concrete tub bottom has survived. The preserved structures of the water tank are supported over a circular reinforced concrete beam with a cross-section of $900 \times 1800 \mathrm{~mm}$ which has rigid fittings by the four outer columns of the tower and the two internal columns of the stairwell. The diameter of the circular beam is $7.8 \mathrm{~m}$. The frame tent with reinforced concrete columns with two rows of reinforced concrete crossbars is made around the water tank to serve as a shield from the atmospheric precipitation. The wall enclosure of the tent is made from bentonite stones [4] $200 \mathrm{~mm}$ thick with reed insulation. The coating of the tank tent is made in the form of a reinforced concrete dome.

In the prismatic part of the tower there is a reinforced concrete staircase for moving between the construction levels and premises for laying water supply pipelines from the tank to the basement of the structure. Floor slabs at different levels of the tower are made from a reinforced concrete ribbed plate, consisting of the main and secondary beams and slab of $80 \mathrm{~mm}$ and $100 \mathrm{~mm}$ thick. 


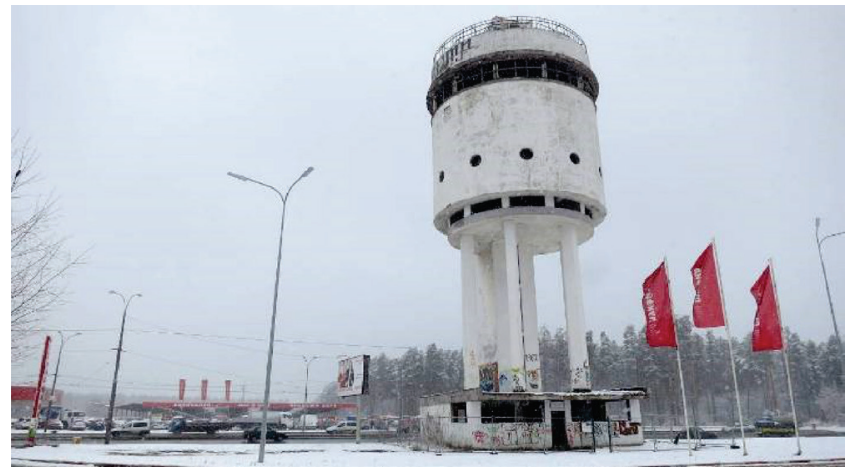

Fig. 2. The current look of the facility.
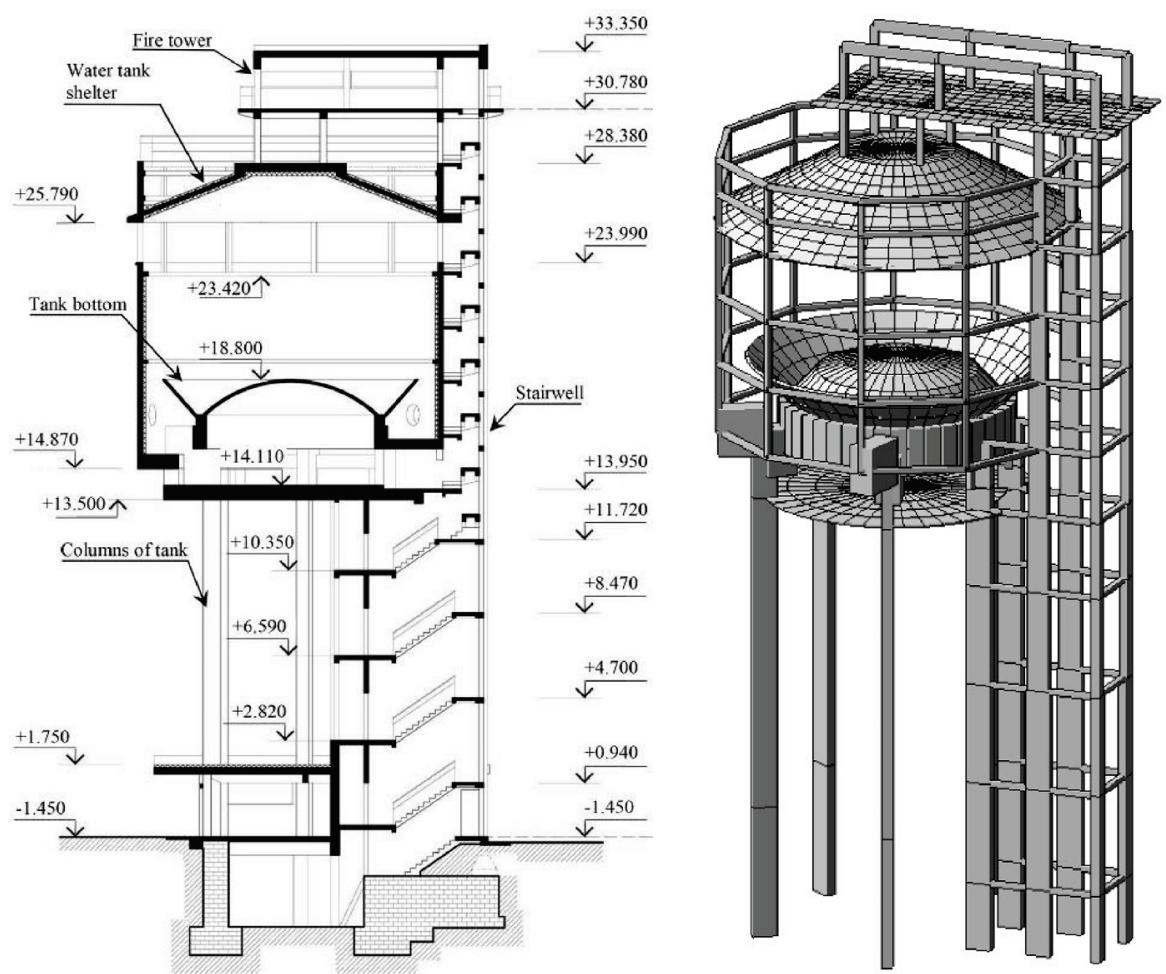

Fig. 3. Cross-section of the tower showing the main structural elements and design scheme of the structure.

Reinforcement of bearing structures is made of hot-rolled bars of steel grade St0 with circular and square cross-sections. In order to reinforce the structures the bars were used executed both in metric and American assortment, for example, 3/8" and 1/2".

\section{The results of structural and technical survey of the tower}

In August 2013 students of the Brandenburg Technical University, Cottbus, Germany under the supervision of Prof. W. Lorenz carried out a survey of the tower [5]. In this work the following major defects and structural damages were noted: damage caused by soaking atmospheric precipitation from the roof and through open window openings in the walls of 
the structure; insufficient or completely absent protective layer of concrete; defects of concreting shaped as shells and voids that appeared due to insufficient compaction of the concrete mixture.

In May 2014 the Research Institute "INTER/TEK" carried out a survey of the bearing structures of the tower [6]. At this survey, numerous defects and structural damages of the tower constructions were noted, caused by two main factors. First of all, the destruction of the waterproofing layer of the coating and the complete destruction of the window glazing structures. Secondly, for a long time the construction was available for unauthorized access by unauthorized persons.

Special attention was paid to the future functional assignment of the construction at the "International Forum of High-Rise and Unique Construction 100+" held in Yekaterinburg on September 23-25 th 2015 [7]. The opinion of the expert community tends to use the facility as an exhibition site devoted to the themes of architectural avant-garde and industrialization in the Urals, but the question of the actual bearing capacity of the structure remains unresolved.
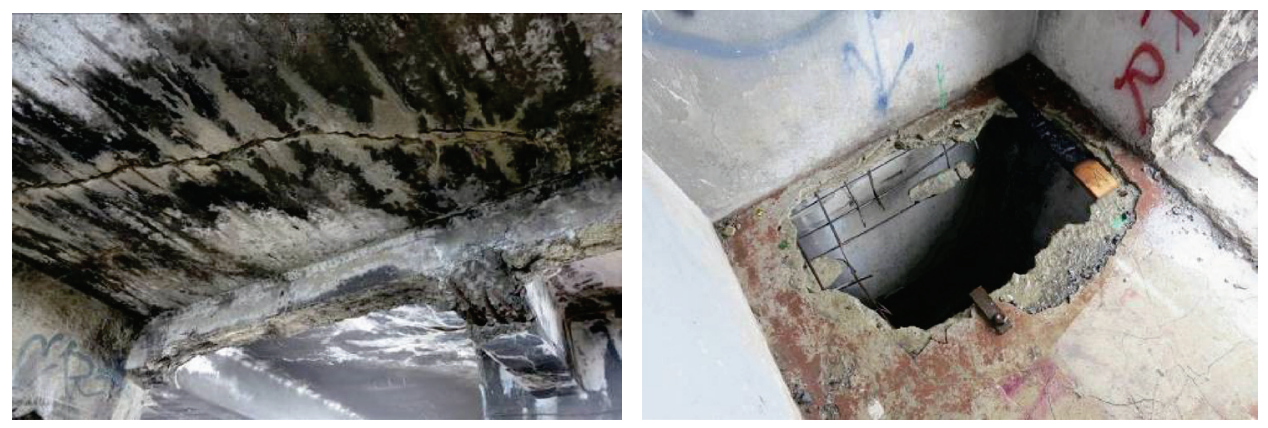

Fig. 4. Typical damages of the structures: cracks in floor slabs, exposure and corrosion of working reinforcement, breaks in the floors.

\section{The bearing capacity of the tower's structures}

To perform the static calculation and determine the design forces in the elements of the bearing structures of the facility, computer modelling of the tower bearing skeleton and its finite element analysis in program LIRA-SAPR 2013 are performed.

Columns, girders and circular beams of the facility were modelled by rod elements. Lamellar finite elements with a size of $0,5 \times 0,5 \mathrm{~m}$ are used for modelling slabs at different levels of structure, the dome of the tank shelter and the preserved bottom of the tank. The grid of lamellar finite elements was compacted in the joints to adjacent structures. The stiffness of the elements of the design scheme was adopted according to the results of the survey and according to the data of the remaining original design documentation.

The calculation is made for two cases of load distribution:

- case 1 corresponds to the current state of the structure;

- case 2 corresponds to the design state of the structure and its operation as a museum.

Dead loads on the structure were taken based on the results of the structural survey. The estimated value of the snow load $\mathrm{s}_{\mathrm{g}}=180 \mathrm{~kg} / \mathrm{m}^{2}$ and the specified value of the wind pressure $\mathrm{w}_{0}=23 \mathrm{~kg} / \mathrm{m}^{2}$ are accepted for the area of the city of Yekaterinburg according to the set of rules SP 20.13330.2011 [8]. The specified live loads on the floors and the staircase structure are taken from SP 20.13330.2011 [8]: for case $1-\mathrm{p}_{\mathrm{n}}=150 \mathrm{~kg} / \mathrm{m}^{2}$ as for the maintenance and repair areas in industrial premises; for case $2-\mathrm{p}_{\mathrm{n}}=400 \mathrm{~kg} / \mathrm{m}^{2}$ as for visual and concert halls and meeting rooms. 
Table 1. The results of estimating the bearing capacity of structures.

\begin{tabular}{|c|c|c|c|c|c|c|}
\hline $\begin{array}{l}\text { Element of } \\
\text { structure }\end{array}$ & $\begin{array}{c}\text { Cross-section } h \times b \\
\text { and the area of the } \\
\text { stretched } \\
\text { reinforcement }\end{array}$ & $\begin{array}{c}M_{\mathrm{x}}, \\
\mathrm{kNm}\end{array}$ & $\begin{array}{c}M_{\mathrm{ult}, \mathbf{x}}, \\
\mathbf{k N m}\end{array}$ & $\begin{array}{l}M_{\mathrm{y}}, \\
\mathbf{k N m}\end{array}$ & $\begin{array}{c}M_{\text {ult,y }}, \\
\text { kNm }\end{array}$ & $\begin{array}{c}\text { Use of } \\
\text { bearing } \\
\text { capacity, \% }\end{array}$ \\
\hline \multirow{2}{*}{$\begin{array}{l}\text { Water tank } \\
\text { columns }\end{array}$} & \multirow{2}{*}{$\begin{array}{c}900 \mathrm{~mm} \times 600 \mathrm{~mm} \\
A_{s \mathrm{x}}=1356 \mathrm{~mm}^{2} \\
A_{s \mathrm{y}}=1808 \mathrm{~mm}^{2}\end{array}$} & 803 & 1101 & 440 & 844 & 72 \\
\hline & & 877 & 1204 & 517 & 948 & 73 \\
\hline \multirow{2}{*}{$\begin{array}{l}\text { Tank shelter } \\
\text { columns }\end{array}$} & \multirow{2}{*}{$\begin{array}{c}300 \mathrm{~mm} \times 300 \mathrm{~mm} \\
A_{s \mathrm{x}}=850 \mathrm{~mm}^{2} \\
A_{s \mathrm{y}}=850 \mathrm{~mm}^{2}\end{array}$} & 74 & 124 & 90 & 108 & 83 \\
\hline & & 86 & 133 & 110 & 119 & 92 \\
\hline \multirow{2}{*}{$\begin{array}{l}\text { Stairwell } \\
\text { columns }\end{array}$} & \multirow{2}{*}{$\begin{array}{c}900 \mathrm{~mm} \times 300 \mathrm{~mm} \\
A_{s \mathrm{x}}=850 \mathrm{~mm}^{2} \\
A_{s \mathrm{y}}=1133 \mathrm{~mm}^{2}\end{array}$} & 424 & 588 & 158 & 264 & 72 \\
\hline & & 471 & 654 & 184 & 288 & 73 \\
\hline \multirow{2}{*}{$\begin{array}{l}\text { Stair } \\
\text { stringer }\end{array}$} & \multirow{2}{*}{$\begin{array}{c}200 \mathrm{~mm} \times 150 \mathrm{~mm} \\
A_{s \mathrm{x}}=380 \mathrm{~mm}^{2}\end{array}$} & 4,5 & 11 & \multirow{2}{*}{-} & \multirow{2}{*}{-} & 41 \\
\hline & & 7,7 & 11,5 & & & 67 \\
\hline \multirow{2}{*}{$\begin{array}{l}\text { "Fire tower" } \\
\text { columns }\end{array}$} & \multirow{2}{*}{$\begin{array}{c}250 \mathrm{~mm} \times 250 \mathrm{~mm} \\
A_{s \mathrm{x}}=253 \mathrm{~mm}^{2} \\
A_{s \mathrm{y}}=253 \mathrm{~mm}^{2}\end{array}$} & 26,1 & 51,5 & 33,9 & 46,5 & 72 \\
\hline & & 30,7 & 56,2 & 38,6 & $\overline{52,0}$ & 74 \\
\hline \multirow{2}{*}{$\begin{array}{l}\text { "Fire tower" } \\
\text { beams }\end{array}$} & \multirow{2}{*}{$\begin{array}{c}400 \mathrm{~mm} \times 200 \mathrm{~mm} \\
A_{s \mathrm{x}}=820 \mathrm{~mm}^{2}\end{array}$} & 88,4 & 124,4 & \multirow{2}{*}{-} & \multirow{2}{*}{-} & 71 \\
\hline & & $\overline{136,6}$ & 147,3 & & & 93 \\
\hline \multirow{2}{*}{$\begin{array}{l}\text { "Fire tower" } \\
\text { floor slab }\end{array}$} & \multirow{2}{*}{$\begin{array}{c}1000 \mathrm{~mm} \times 80 \mathrm{~mm} \\
A_{s \mathrm{x}}=427 \mathrm{~mm}^{2}\end{array}$} & 2,48 & 4,17 & \multirow{2}{*}{-} & \multirow{2}{*}{-} & 59 \\
\hline & & 3,90 & 4,17 & & & 94 \\
\hline
\end{tabular}

In the above table, the values above the line refer to the first case for calculating the structure - under the action of existing loads; the values below the line refer to the second case for calculating - under the action of the estimated loads.

Values for the strength of concrete for compression $\mathrm{R}_{\mathrm{b}}=85 \mathrm{~kg} / \mathrm{cm}^{2}$ and the strength of reinforcing steel for tension $\mathrm{R}_{\mathrm{s}}=1600 \mathrm{~kg} / \mathrm{cm}^{2}$ are taken from structural survey in accordance with the recommendations of SP 13-102-2003 [9].

The bearing capacity of the building structures of the facility was evaluated using the critical force approach, laid down in SP 63.13330.2012 [10] from expression

$$
M \leq M_{\text {ult }},
$$

where $M-$ is the bending moment from the external load;

$M_{\text {ult }}$ - is the ultimate bending moment, that can be perceived by cross-section of the element according to SP 63.13330.2012 [10].

The bending moment for elements subject to bending was taken from the static analysis. The bending moment for elements subject to eccentric compression was determined from the formula

$$
M=N \cdot e,
$$

where $N$ - is a longitudinal force from external load, determined from static analysis;

$e-$ is a distance from the point of application of the longitudinal force to the centre of gravity of the section of the stretched or least compressed reinforcement.

Due to the structural features of the facility, most of the tower columns are under conditions of a complex stress-strain state and are subject to oblique eccentric compression [11], therefore the following condition was additionally checked 


$$
\left(M_{\mathrm{x}} / M_{\mathrm{ult}, \mathrm{x}}\right)^{\mathrm{k}}+\left(M_{\mathrm{y}} / M_{\mathrm{ult}, \mathrm{y}}\right)^{\mathrm{k}} \leq 1,
$$

where $M_{\mathrm{x}}$ and $M_{\mathrm{y}}$ - are the bending moments from the external load relative to the centre of gravity of the cross section of the element in two mutually perpendicular planes of symmetry of the cross section;

$M_{\mathrm{ult}, \mathrm{x}}$ and $M_{\text {ult,y }}$ - are ultimate bending moments, that the element cross section can be perceived in the planes of symmetry;

$\mathrm{k} \leq 1,6$ - numerical factor, depending on the boundary height of the compressed area of concrete and steel ratio of concrete.

\section{Conclusions}

It is established that the main constructions of the structure have sufficient bearing capacity to place the museum in the tower. It is worth noting that the planned live loads that will affect on the tower's construction structures are not the main ones, i.e. the loads that are causing the main loads onto the elements. The main impact, which makes the greatest contribution to the exhaustion of the bearing capacity of the elements of the structure, is the weight of the structures themselves. Live loads that will arise in the construction when operating it as a museum are the main ones for the floor slab of "fire tower", the structures of the stairs and the columns of the tank shelter. The last one is the weakest part of the entire structure.

The author hopes that this work will allow carrying out a complex of activities for the restoration of the building structures of the facility and will help in deciding whether to develop one or another alternative for its adaptation.

\section{References}

1. White tower. Available on http://www.tower1929.ru/ (2017)

2. M.V. Reisher. Memories of the construction of the tower. Archive of the Museum of the History of UZTM. Yekaterinburg (1971)

3. I.A. Kazus. Soviet architecture of the 1920s. Organization of design (2009)

4. S.L. Prokhorov. Recent achievements in the construction of bentonite stones. Modern Architecture, 2, 49-60 (1928)

5. O. Arkhipkina, G. Albrecht. Untersuchung, Bemessung und Bewertung historischer Bausubstanz - Der "Weiße Turm" in Jekaterinburg (Russland): Aufgabenstellung für eine Bachelorarbeit im Studiengang Bauingenieurwesen. Cottbus (2013)

6. S.V. Kudryavtsev, Y.V. Gurjanov. Technical report 05-2014-OBS. Visual inspection and assessment of the technical state of the water tower at: Yekaterinburg, ul. Bakinskih Commissarov, 2a/1 for the development of the project of conservation of facility. Research Institute "INTER/TEK". Yekaterinburg (2014)

7. International Forum of High-Rise and Unique Construction 100+. Available on http://www.forum-100.ru (2015)

8. SP 20.13330.2011. Set of rules. Loads and effects (2011)

9. SP 13-102-2003. Set of rules. Rules for inspection of bearing constructions of buildings and structures (2003)

10. SP 63.13330.2012. Set of rules. Concrete and reinforced concrete structures. Principal rules (2012)

11. S.V. Kudryavtsev. Evaluation of bearing capacity of concrete thickeners with carbon plastic reinforcement. Akademicheskij Vestnik UralNIIproekt RAASN, 2, 91-96 (2013) 